\title{
The Journal of Contemporary Administration (RAC)'s 2018-2021 Managerial Report and a Farewell
}

Relatório de Gestão da Revista de Administração Contemporânea 2018-2021, e Farewell

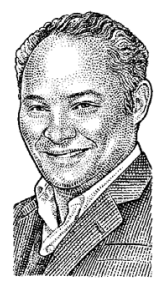

Wesley Mendes-da-Silva*1,2

This is the last editorial that I am writing as the Editorin-Chief of the Journal of Contemporary Administration $(R A C)$, completing my predefined voluntary pro bono mandate (2018-2021). I would like to take this moment to thank and recognize the professional work of several people with whom I've had the great opportunity to work and learn from during the past three years. In saying farewell to this position, I will leave you with a brief summary of the work we have performed from June 2018 to May 2021 in order to follow the editorial best practice of providing information (Bandi \& Patton, 2019; Kumar \& Zattoni, 2019).

Conscious of the duties and responsibilities inherent in the role of Editor-in-Chief (Aguinis \& Vaschetto, 2011), at the $R A C$, I have constantly sought to prioritize the interests of the Brazilian business community in countless initiatives during my tenure. To accomplish this, I have counted on the invaluable collaboration of people of rare dedication and a rare sense of professional duty, among whom I would like to name: Case Study Editor Paula Chimenti (CoppeAd/Universidade Federal do Rio de Janeiro/Brazil), who has expanded on the work started by Victor Almeida (CoppeAd/Universidade Federal do Rio

* Corresponding Author.

1. Fundação Getulio Vargas, Escola de Administração de Empresas de São Paulo, São Paulo, SP, Brazil. 2. Editor-in-chief of the Journal of Contemporary Administration (RAC). de Janeiro/Brazil), and the Tutorial Article and Open Data Editor Henrique Martins (Pontificia Universidade Catolica do Rio de Janeiro/Brazil). I would also like to thank associate editors Eduardo Flores (Universidade de São Paulo/Brazil), Emílio Arruda Filho (Universidade da Amazonia/Brazil), Fabio Caldieraro (Ebape/Fundação Getulio Vargas/Brazil), Gilnei L. Moura (Universidade Federal de Santa Maria/ Brazil), and Paulo Matui. I would especially like to recognize the guest editors of our Special Issues: Airton Cardoso Cançado (Universidade Federal do Tocantins/Brazil), Ali Rostron (University of Liverpool/United Kingdom), Angela Paladino (University of Melbourne/Australia), Aureliano Angel Bressan (Universidade Federal de Minas Gerais/Brazil), Benilde Oliveira (Universidade do Minho/ Portugal), Cristiana Fernandes de Muylder (Universidade FUMEC/Brazil), Cristiana Leal (Universidade do Minho/ Portugal), Eduardo Schiehll (HEC Montréal/Canada), Elin M. Oftedal (University of Stavanger/Norway), Emiliano A. Valdez (University of Connecticut/USA), Evelyn Lanka (EAESP/Fundação Getulio Vargas/Brazil), Giovanna Bertella (UiT The Arctic University of Norway/Norway), Ines Branco-Illodo (University of Stirling/United Kingdom), Jairo Laser Procianoy (Universidade Federal do Rio Grande do Sul/Brazil), João Vinícius Carvalho (Universidade de São

Cite as: Mendes-da-Silva, W. (2021). The Journal of Contemporary Administration (RAC)'s 20182021 managerial report and a farewell. Revista de Administração Contemporânea, 25(6), e210100. https://doi.org/10.1590/1982-7849rac2021210100.en 
Paulo/Brazil), Luiz Ricardo Kabbach de Castro (University of Florida/USA), Małgorzata Grzegorczyk (University of Lodz/Poland), Marcelo S. Perlin (Universidade Federal do Rio Grande do Sul/Brazil), María Luisa Esteban Salvador (Universidad de Zaragoza/Spain), Pallavi Singh (Sheffield Hallam University/United Kingdom), Petra Molthan-Hill (Nottingham Trent University/United Kingdom), Ruby Roy Dholakia (University of Rhode Island/USA), and Sanjay Lanka (EAESP/Fundação Getulio Vargas/Brazil).

I would also like to register my sincere and honest acknowledgement of the tireless work of the individuals who have ensured the seamless functioning of $R A C$ s Editorial Office: Kler Godoy, Nadia Machuca (who is no longer a member of Anpad), and Simone Rafael. I would also, naturally, like to thank Anpad for the confidence they have placed in me and the independence I have been granted. I would like to thank my colleagues who work in institutions outside of Brazil, who accepted being part of the editorial team during my time here: John L. Campbell (University of Georgia), Marcus Cunha Jr. (University of Georgia), James Robert Moon Junior (Georgia Tech), Erica Piros Kovacs (Kelley School of Business, Indiana University), Julian Cardenas (Frei University/Germany), and Elin Merethe Oftedal (University of Stavanger/Norway).

Finally, we know that few understand the nature of academic work, especially in terms of the time dedicated to performing professional activities for the community, and therefore it is only fitting that I thank my family for their understanding of my absences while managing and furthering the $R A C$ s editorial process.

\section{A BRIEF SUMMARY}

At the end of the first semester of 2018, I received the responsibility of producing articles pertaining to $R A C s$ editorial process (Kimura, 2018). As soon as I assumed the position of Editor-in-Chief at the $R A C$, I sought to make clear the path I would follow during my tenure from 2018 to 2021: promoting transparency in the editorial process and especially in the research published by the journal, with the intention of replacing discourse with action (Mendesda-Silva, 2018a). Thus, from the first issue, we began publishing articles with open data, in order to position the journal in the vanguard in terms of the adoption of the precepts of open science within the Brazilian context of business studies. Gradually over time the open science policy has been reflected by peer review, the Tutorial Articles, and the Executive Letters, which our editorials have detailed in advance for the knowledge of our community.

In parallel to the typical activities of the position, in order to begin executing the plan presented to Anpad when I was recruited as the journal's Editor-in-Chief, I sought to submit the $R A C$ to the indices that did not include it. A series of these indices accepted the journal without difficulty. However, the two with the greatest international recognition, Scopus and the Web of Science, presented (in their responses a few months later) a variety of concerns that included the fact that we did not have an English version of the website (hindering a better understanding of the journal's activities) and even the layout of the published articles.

Given the concerns presented by the indices, we began to work on meeting these demands, and this effort led us to achieve the following principal advances (some of them are registered in the 2018-2019 managerial report (Mendes-da-Silva, 2019c), among others that I will not list due to a lack of space:

1. The construction of a new expanded $R A C$ website on the Open Journals platform, which made it possible to: reduce costs and response time, have greater flexibility in the journal's managerial process, have greater autonomy for the editorial staff, and have a better professional presentation of the journal.

2. A reform of the Scientific Editorial Board to reduce endogeneity on various levels.

3. The offering of English and Spanish versions of the entire $R A C$ website's content, especially in terms of new editorial policies, in order to ensure more and better communication with international players, e.g., readers, authors, and indexing agents.

4. The redefinition and consolidation of the innovative scope of the $R A C$ as a journal of international reputation focused on themes of regional interest.

5. The initiation of maintenance procedures for the certification of the Editor-in-Chief of the $R A C$ by the Council of Science Editors (CSE).

6. An increase in communication with colleagues from other countries through invitations to edit special issues in line with the Sustainable Development Goals of the United Nations (https://sdgs.un.org/ goals retrieved on March 11, 2021). This led to greater use of the $R A C$ by researchers in the United States, the United Kingdom, Germany, Portugal, Spain, and Norway, among other nations.

7. The creation of the Tutorial Article section, one of a new class of relevant publications whose focus is methodology, in a way that permits autonomous learning on the part of researchers, and a reduction in the redundant effort made in research. It also promotes the effective sharing of ideas, in line with the practices of open education within the context 
of the principles of open science (Martins, 2020; Mendes-da-Silva, 2018a, 2019b).

8. The creation and redefinition of editorial policies in relation to indexation and ensuring the quality of the editorial process, as requested by the COPE Committee on Publication Ethics.

9. The construction and adoption of a new layout for the documents published by the $R A C$ (here I would like to note the professional work of Ms. Kler Godoy), in order to permit the quicker, more professional, and efficient communication of content (Mendes-daSilva, 2019a). In this area, we can also mention: (a) the JEL code (the classification system developed by the Journal of Economic Literature) of each article, (b) the number of invitations sent to the reviewers until the editorial decision was deemed viable, (c) the adoption of structured summaries and the annotation of the contributions of each participating individual within the authorship according to the CRediT taxonomy, and (d) four levels of classification (discipline, theme, sector of activity, region) for the Case Studies in order to facilitate the rapid identification of the preferred audience for each Case Study.

10. The adoption of the policy to publish all documents in English to establish the journal's position, not in terms of the languages it adopts, but rather its thematic scope, helping construct a distinctive identity for the $R A C$.

11. The establishment of the Open Science Editorial policy that managed the journal's interests in terms of its everyday and strategic activities in the editorial process, which sought to consolidate the $R A C$ as a reference in open science.

12. The gradual opening up of data, codes, material, and reviews of works published by the $R A C$ of a quantitative or qualitative nature. In addition to the traditional arguments in favor of open science, we have also sought to describe an externality that we turned into something positive: inhibiting the practice of salami science (Mendes-da-Silva \& Leal, 2021).

13. The addition of an environment on the $R A C$ website that is dedicated to organizing and disseminating audiovisual material related to the journal's activities as a way of collaborating with the increasing use of social media to increase the diffusion of the journal and its publications (https://rac.anpad.org.br/index.php/rac/media retrieved on March 11, 2021).
14. The submission and entrance of the $R A C$ in international indices as a way to increase the diffusion of the journal's published works, for example:
a. CiteFactor
b. COPE
c. Econpapers/Ideas (RePEc)
d. ERIHPlus
e. Europub
f. ICI Index Copernicus International
g. Latindex. Catalog v2.0
h. MIAR
i. Redib
j. Sherpa/RoMEO
k. CARHUS Plus+

15. Successive submissions until the RAC was accepted (at the end of 2020) for the COPE listing, which represented a concrete indication to indices and the $R A C$ audience of the quality and rigor of the editorial process practiced by the journal.

16. The publishing (in volume 25 , number 4,2021 ) of the Executive Letters section, which increases the communication with Administration practitioners and at the same time provides relevant information to the research community regarding content that deserves the highest priority in the eyes of the individuals working on the cutting edge of Administration.

\section{Establishment of a distinctive identity and an innovative scope for the RAC}

The identity of the $R A C$ has evolved over time as has been narrated by Rossoni and Rosa (2020). However, something that appears to be true is that the journal has achieved relative success in positioning itself as a notable journal, even though this does not imply that there is no work to be done in terms of delineating and consolidating the journal's distinctive identity, including its scope. Thus, in order to make sure that we do not fail to highlight the $R A C$ 's archive and community, in this editorial cycle, we will seek to attribute clearer frontiers to the scope and the contributions of the journal to society. As our first activity at the beginning of my editorial tenure, I opted to invest effort in the definition of a visual identity that would better characterize the $R A C$, including the construction of an entirely new website that was more informative and responsive (Figure 1). 

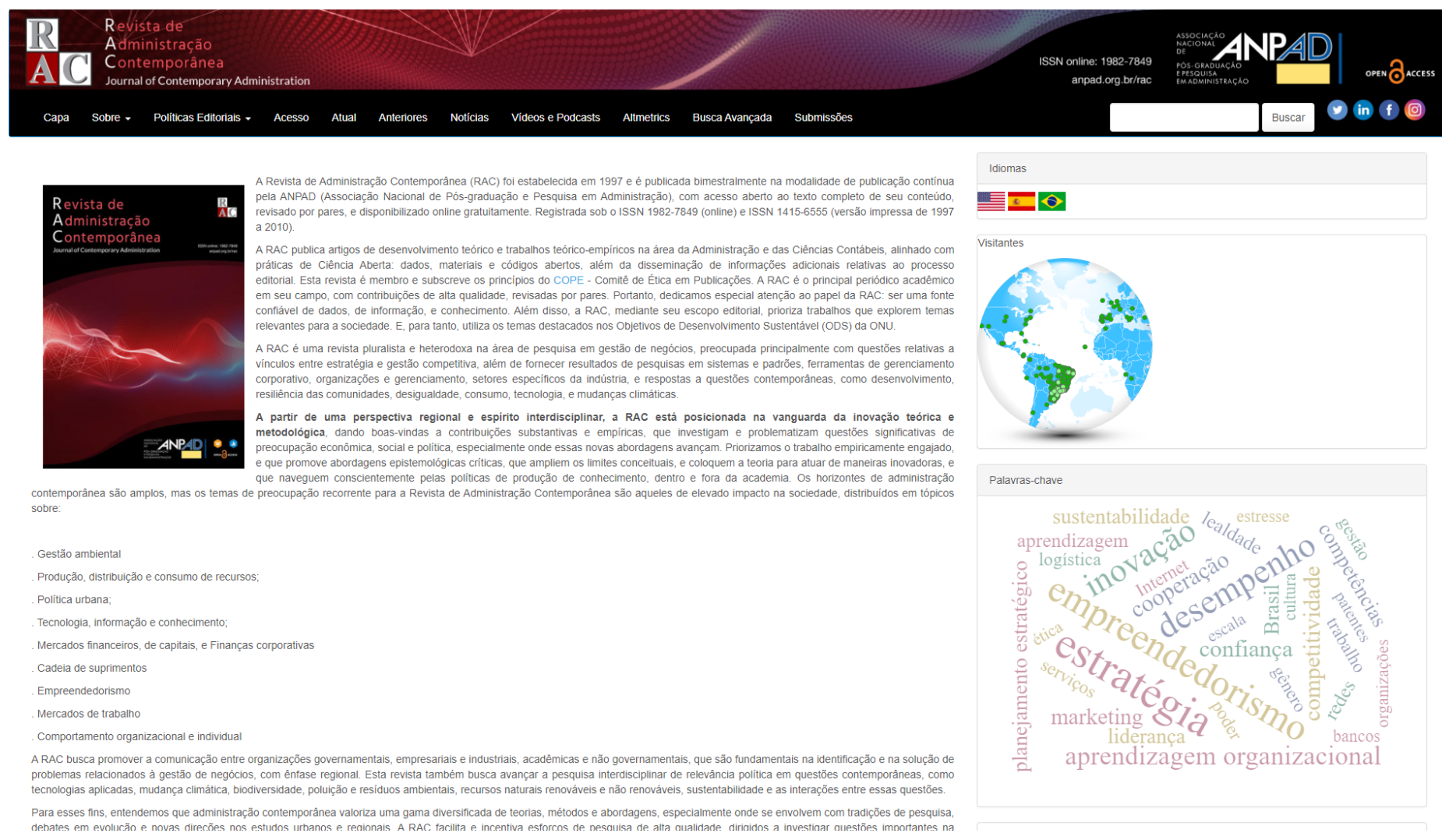

Figure 1. View of the Journal of Contemporary Administration (RAC) website.

Source: The $R A C$ website, accessed on March 9, 2021. This figure is available at: http://doi.org/10.5281/zenodo.4591556.

Beyond the aesthetic aspects and the graphic presentation, there was a special concern with indicating to the community what the $R A C$ intended to publish at that time, i.e., works aligned with the principles of open science and works that contributed to the debate about the SDG agenda, and this implied the adoption of a group of new planned special issues, as follows:

1. Nudging and Choice Architecture (Leal, Oliveira, Branco-Illodo, \& Salvador, 2020): underway.

2. Research Methods in Qualitative Management Research (Lanka, Lanka, Ronstron, \& Singh, 2019): underway.

3. Insurance Industry (Carvalho, Flores, \& Valdez, 2020): underway.

4. Data Reuse: What New Information Can We Learn from Used Data? (Martins \& Perlin, 2020). No article was selected. We suspect that more publicizing and better community information about the potential reuse of data for new works could be valuable inducers of the reuse of data.

5. COVID-19's Impact on Businesses (Chimenti \& Marques, 2020): 16 Case Studies dedicated to lessons learned during the COVID-19 pandemic in Brazil, published in volume 25, Special Issue of 2021 (Marques, Chimenti, \& Mendes-da-Silva, 2021).

6. Business Models at the Crossroad of Responsible Innovation, Sustainability and Resilience (Oftedal, Bertella, Grzegorczyk, Hill, \& Lanka, 2020): published in volume 25, number 3, 2021.

7. Tutorial Articles: Guiding the Practice of Quantitative Research (Martins, 2019): published in volume 25, number 1, 2021.

8. Corporate Governance in Family Businesses (Mendes-da-Silva, 2018b): published in volume 23, number 6, 2019. I would like to register here an acknowledgement of the partnership established between the $R A C$ and the Brazilian Institute of Corporate Governance (IBGC) in the production of this special RAC issue.

9. Technology Perspectives and Innovative Scenarios Applied in the Amazon Region (Arruda Filho, Muylder, Cançado, Dholakia, \& Paladino, 2019): published in volume 23, number 5, 2019. 
During my editorial tenure, I have sought to optimize the quality of the journal within the context of its distinctive identity. In this sense, I would like to emphasize that aspects that have been derived from this, such as internationalization, have not been treated as an end per se, but rather as an external consequence. That is, the premise was to do what has to be done, and the scientific journal naturally will assume its position in concert with periodicals of quality (in the sense of contributing to society beyond the research community).

In terms of the practices of open science, notably the sharing of data and material, with there being no unanimity among the relevant authors, editors, and players, such as Scielo and COPE, we expressed explicit guidelines to promote the gradual and irreversible public sharing of data, material, collection codes, data analyses, evaluator reports, and other portions of the editorial process.
Keeping this movement in mind, work continues at the $R A C$ in this sense, and the editors of the $R A C$ voluntarily accept invitations or answer requests regarding practices and knowledge, as was the case with the 8th Annual Scielo Meeting (Figure 2), the Anpad meetings, local scientific events, and other journals edited in Brazil whose individual editors are interested in adopting and emphasizing the practices of open science.

However, the effort spent on open science has also required an alignment with reasonably established international practices. In this sense, the $R A C$ has sought to be in close contact with relevant individuals and organizations in the academic community to accompany the modern practices that are classified as the most appropriate. An illustration of this has been the customary participation of the $R A C$ in the Council of Science Editors - CSE Meeting 2019 (Figure 3), an event in which researchers, editors, and publishers from diverse areas of knowledge meet regularly to exchange ideas.

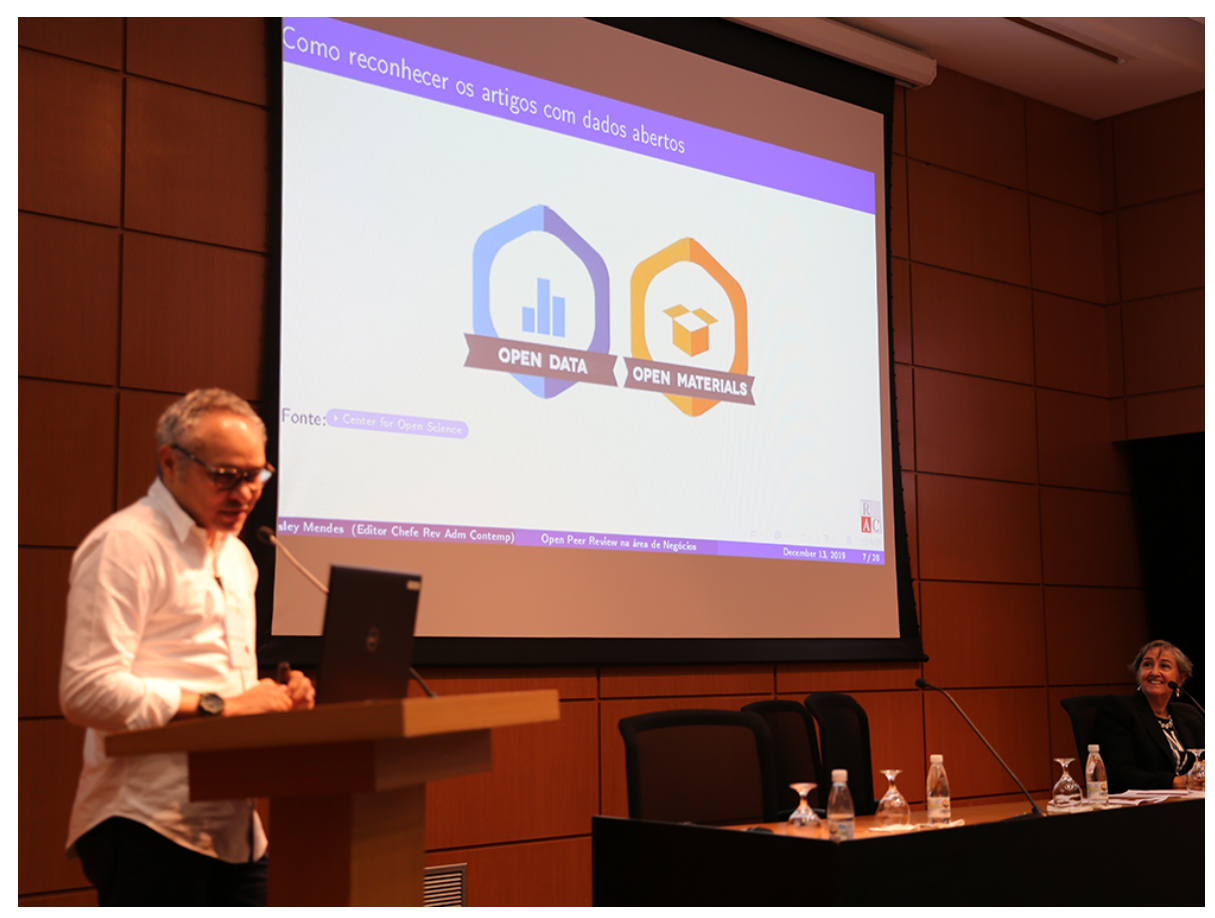

Figure 2. The Journal of Contemporary Administration ( $R A C$ ) presentation at the 8th Annual Scielo Meeting in 2019, speaking about open science practices adopted by the $R A C$.

Source: Gallery of photos from the 8th Annual Scielo Meeting (São Paulo, December 13, 2019). Available at: http://eventos.scielo.org/viiireuniaoscielo/galeria-de-fotos/. The presentation can be seen in its entirety at: http://doi.org/10.5281/zenodo.3574011. 


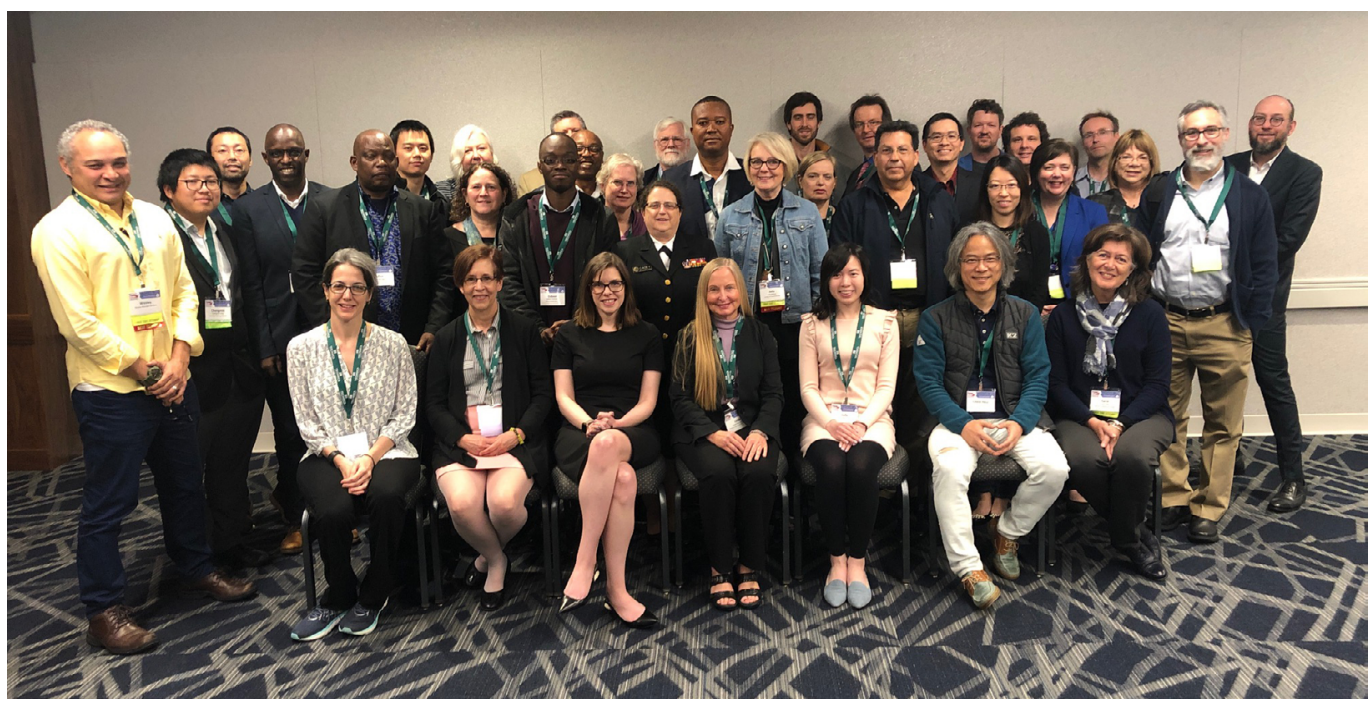

Figure 3. Participants in the Scientific Editor Course at the 2019 Council of Science Editors Meeting. Source: Kindly provided by Christine G. Casey (Centers for Disease Control and Prevention), one of the participants in the 2019 Council of Science Editors Meeting, May 4-5, 2019 in Columbus, Ohio.

As open science practices have become established at the $R A C$ and new articles have been published, gradually the identity of the journal has taken on a clearer shape, which has resulted in its editorial positioning and its contribution to society as a source of knowledge and reliable data. Based on its increased importance, which still requires further development, we have begun to see signs of the impact of some $R A C$ practices and initiatives.

An example of this is giving authors and reviewers the option to make their dialogue public during the manuscript evaluation process, and happily a significant portion of works (Articles and Case Studies) reveal the identities of the individual evaluators and especially the entire content of the reports. This enables our new evaluators and authors to use this new and valuable content to develop their abilities. The recognition of the voluntary work of evaluators (Mendes-daSilva, 2018c) is a point that deserves special attention from the editor, and these practices have had a positive impact on the reviewers at the $R A C$ (Figure 4).

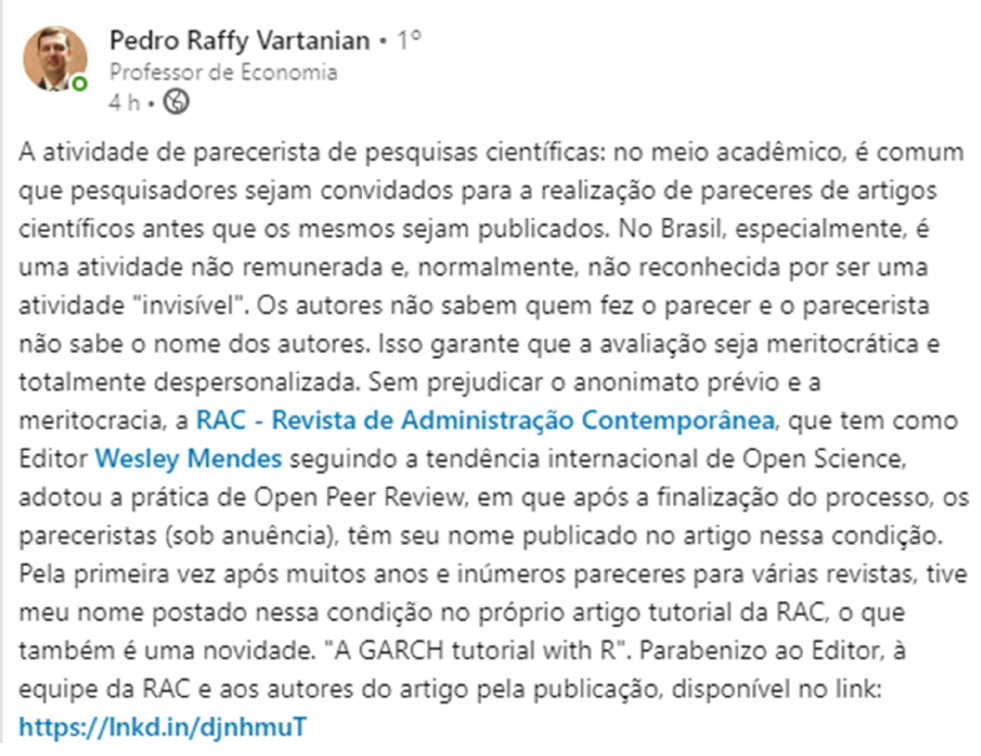

Figure 4. Reproduction of a social network post published by a voluntary reviewer at the Journal of Contemporary Administration (RAC).

Source: Post published by Professor Pedro Raffy Vartanian (ORCID: https://orcid.org/0000$\underline{0002-1492-7128}$ ) on a social network regarding the OPR adopted by the $R A C$. 
It is evident that we need to invest strongly in the training of reviewers, and the $R A C$ is even thinking of supporting a free structured and formalized program to develop and certify reviewers, similar to the successful ACS Reviewer Lab of the American Chemical Society (2017). We all know the relevance of good evaluations, but unfortunately, we still do not have a system that permits the structured instruction of individuals to produce good reports, and we need to invest in this professionalization and recognition agenda as a community.

When we look specifically at the $R A C$ s open data archive, we can observe that of the 948 articles published by the $R A C$ between January 1997 and December 2021, almost 60 have open data and/or material. The data policy was adopted in May 2018, and it was gradually encouraged until it became mandatory for submitted works at the end of 2020 .

Authors who wish to check open data and/or material for articles published in the $R A C$ before May 2018 can do so without difficulty by following the instructions provided by the $R A C$ s Editorial Office. An example of this is a work by Mendes-da-Silva, Onusic and Giglio (2013), which originally did not offer open data, but came to offer open data in 2018 (see the year 2013 in Figure 5). Thus, there is room for a portion of the articles already published by the $R A C$ to be in line with the modern policy of open science (PLOS Media, 2021).

\section{A LITTLE BIT ABOUT NUMBERS}

For close to 25 years, the $R A C$ has published a variety of documents that range from scientific articles to our recent Executive Letters. During this time, almost 950 new scientific articles have been made available to society for free, with almost 60 of them offering free access to the data and/or material used in developing the research (Figure 5), which can assist new researchers. As we can see in Figure 5 , since 2018 the number of articles with open data and/or material has been growing quickly. In contrast, the number of articles that do not have at least an explanation from the authors of the work for not sharing the data (secret data) has gradually diminished and recently (at the end of 2020) the $R A C$, in complying with the procedures adopted by Scielo, and in line with COPE, has made the sharing of data mandatory.

In certain situations, the data may not end up being shared, but in these cases, the analysis code always has to be shared, in case there has been some type of analysis, even if it is qualitative. One aspect that deserves attention and development is the intensification of the open data and material policy for studies of a qualitative nature (Aguinis \& Solarino, 2019; Moravcsik, 2014; Plakoyiannaki, Wei,
\& Prashantham, 2019). As highlighted in the previous editorial (Mendes-da-Silva, 2019b, p. 3): "It is already possible to perceive in the international community initiatives to classify journals according to the typical replicability of their published research, for example: https://replicationindex.com/tag/replicability/".

That is, the benefits that come from the sharing of data and material do not come exclusively from quantitative studies or from replicability: (a) they constitute an attribute that applies to any study, which implies the possibility of an individual researcher being interested in repeating the research in terms of which level of replication is under consideration, or (b) are a way to ensure that the minimum requirements attest to the reliability and validity of the results of a qualitative study (Ethiraj, Gambardella, \& Helfat, 2016; Lecompte \& Goetz, 1982; Mendes-da-Silva, 2019b; Tsang \& Kwan, 1999). However, we cannot forget that in the final analysis the researcher is responsible for the appropriate use and storage (and/or sharing) of his or her research data.

In terms of interest from other countries in content published in the $R A C$, we may observe Figure 6 , in which we can verify that in terms of the volume of visits to the journal's website, the United States (around 8,500 visits) and Portugal (around 6,500 visits) have been the countries with the most visits, followed by Panama, Mozambique, the United Kingdom, Angola, Mexico, Colombia, Germany, and Spain.

In terms of the RAC still not being on the list of the journals of the highest quality, which personally I imagine may be rectified very soon, it is possible to note the great attention received by the journals on these lists. In this respect, in the Brazilian journals listed on Scopus, works published in the $R A C$ have been cited more than 1,600 times. Figure 7 presents the frequency of Scopus citations by country (left side in Figure 7), and by journal (right side in Figure 7).

The proportion of the citations that come from Portugal, the United States, and the United Kingdom is notable. Even so, in terms of journals, the $R A C$ is still relatively restricted to citations from journals published in Brazil (especially the Revista de Administração Mackenzie, Revista de Administração de Empresas and Revista de Administração Pública), it is probably reasonable to expect, with the recent adoption of the publication of the archive in its entirety in English and with the full establishment of the open science policy, a gradual increase in the total of citations and the portion coming from other countries.

When we observe the number of citations received by the $R A C$ originating from another relevant international index, the Web of Science, we find 872 works published in 
the $R A C$, which have received 3,321 citations as of March 3 , 2021. Table 2 presents a list of the 50 most often cited documents in the Web of Science as of the beginning of March 2021, with the text titled "Construindo o conceito de competência," published in volume 5 , a special issue in 2001, having the most citations with 107.

Therefore, in the two platforms that count international citations, Scopus and the Web of Science, the RAC displays a substantial number of citations. This fact, together with a number of advances in a variety of aspects in the editorial process, makes it reasonable to suppose that soon the journal will appear on these lists, which will likely lead to an increase in the quantity and quality of the articles published by this journal.

Even though it is not the main reason for this editorial management report, it should be noted that the EIC does not have any decision-making power in terms of the financial management of editorial activities, either in budgetary planning or in its execution. The management of these aspects has been restricted to the president and directors of Anpad during my tenure (May 2018 to May 2021).

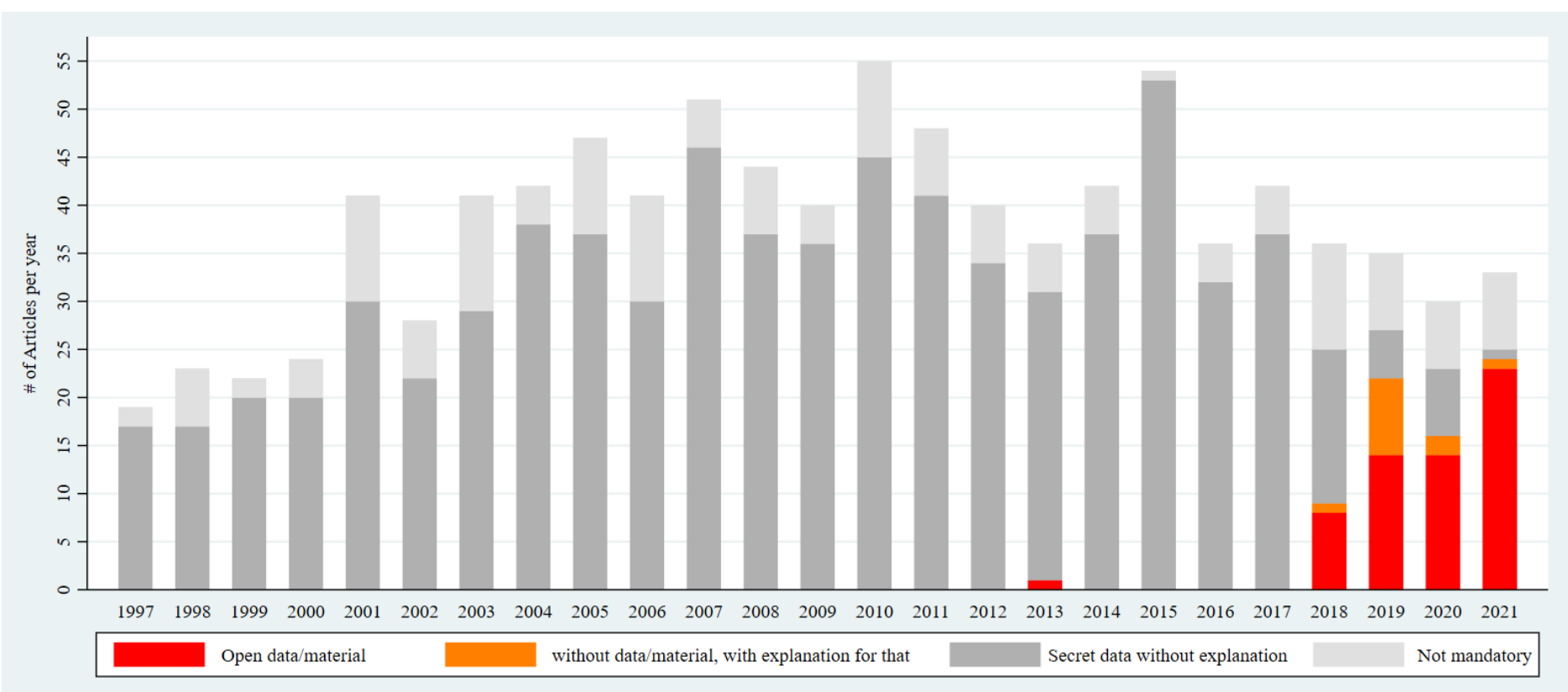

Figure 5. Evolution of the number of articles published by the $R A C$ and the proportion of articles with open data and/or material (1997-2021).

Source: Prepared by the author based on data provided by the $R A C$ s Editorial Office. Note: This figure presents the evolution of the number of articles published by the $R A C$ since its founding (1997), identifying the proportion of articles that share data and/or material. The open data policy began in June 2018, and one article published in 2013 made its data open in 2018. The author examined the content of each of the 948 articles to classify them in one of the four categories reported here. This figure is available at: http://doi.org/10.5281/zenodo.4591556. 


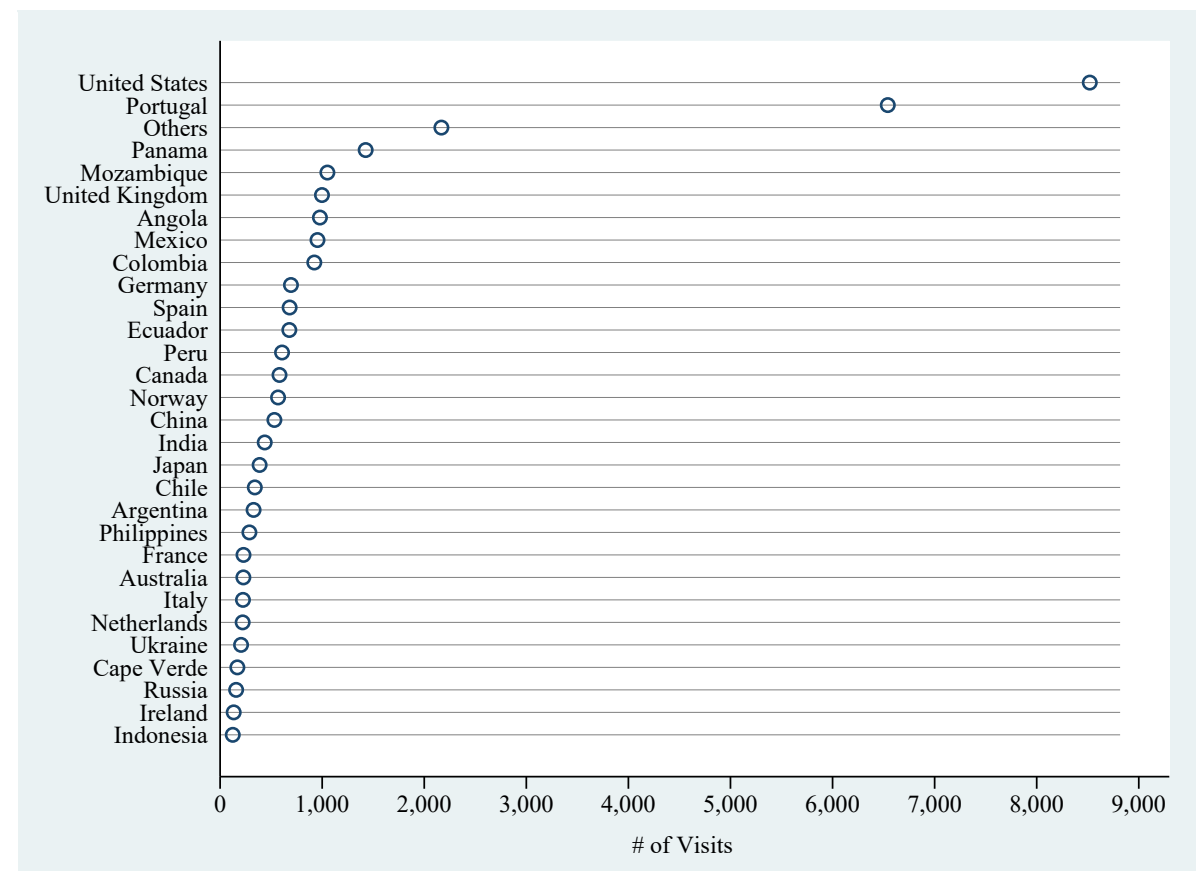

Figure 6. List of the 30 countries that have visited the $R A C$ website most often (October 2018 to February 2021).

Source: Editorial Office of the Journal of Contemporary Administration $(R A C)$. This figure presents the 30 countries that have visited the $R A C$ website most often from October 2018 to February 2021. Brazil, which is absent from this figure, had 475,190 visits. The country with the second highest frequency was the United States with 8,520 visits, with the leading cities being respectively Redmond, WA; Atlanta, GA; Chicago, IL; and San Jose, CA. Besides the United States, Portugal $(6,541)$, Panama (1,426), and Mozambique $(1,051)$ are the countries with at least 1,000 visits. The 'Other' category had 2,168 visits from countries with at least 124 visits, which is the number that was registered for Indonesia. This figure is available at: http://doi.org/10.5281/zenodo. 4591556.

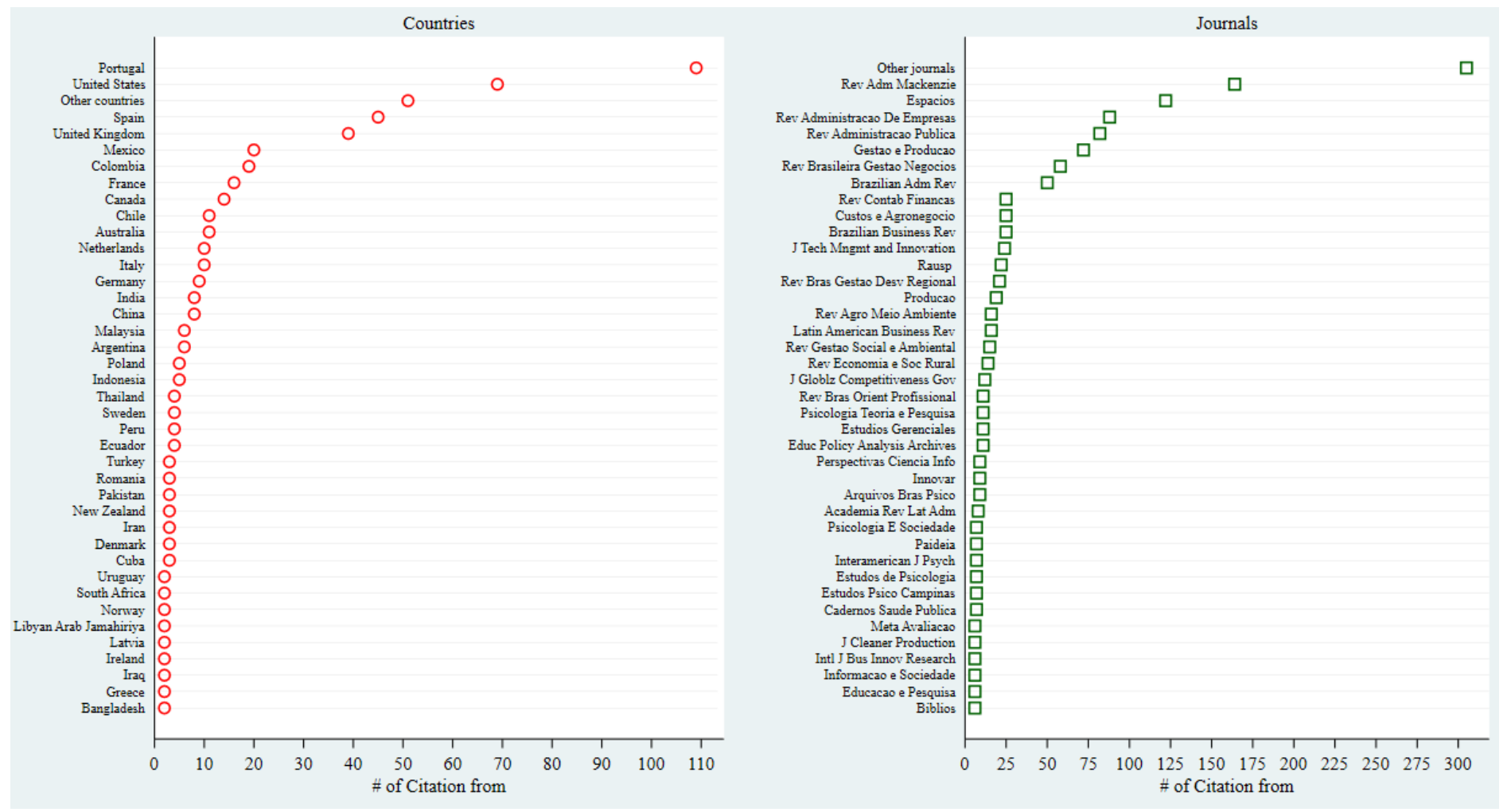

Figure 7. Scopus index citations of the Journal of Contemporary Administration $(R A C)$ in terms of the journal and the citation's country of origin $\dagger$.

Source: Prepared by the author based on data kindly collected by Professor Luciano Rossoni on the Scopus platform (on March 3, 2021). This figure presents in decreasing order the 40 most frequent sources among the citations of the $R A C$ on the Scopus platform. The most frequent countries, led by Portugal with 109 citations and the United States with 69, appear on the left. $\dagger$ Brazil, for better visualization of the scale, is absent from the figure on the right, with there being 1,600 citations from this country. The journals appear on the right led by the Revista de Administração Mackenzie. The RAC over time came to publish its entire archive in the English language beginning in January 2020. This figure is available at: http://doi.org/10.5281/zenodo.459155. 
The $R A C$ s editorial process occurs through a collaboration between authors, reviewers, and editors as well as the actions of the $R A C$ s Editorial Office, proofreading service providers, and support in the preparation of alternative document formats to meet the indices' criteria. These players together end up determining how quick and demanding the work is, which results in the published documents. Thus, it is a never-ending work that is always evolving. Therefore, we need to pay special attention to the various phases of the process that are characterized by indicators. Below in Table 1 we summarize the main indicators of the work performed by the $R A C$ between the first semester of 2019 and the second semester of 2020 . We can observe a gradual reduction $(-54 \%)$ in the editorial cycle, which is mainly due to the alacrity with which the reviewers reported their opinions on the submitted works, as well as a decrease in the number of articles that underwent peer review in order to save the time and effort of the evaluators and especially the authors.

Table 1. Characterization of the speed of the editorial process at the Journal of Contemporary Administration (RAC) (first semester of 2019 to second semester of 2020).

\begin{tabular}{lcrr}
\hline & & \multicolumn{2}{c}{ Semester } \\
\cline { 2 - 3 } Indicator & $2019 / 1$ & $2020 / 1$ & $2020 / 2$ \\
\hline Total number of articles submitted & 150 & 167 & 175 \\
Articles under evaluation & 100 & 63 & 16.7 \\
Articles accepted and published & 12 & -50.0 & 0.0 \\
Articles accepted for publication & 8 & 15 & 30 \\
Average time (days) between submission and publication & 133 & 78 & 61 \\
\hline
\end{tabular}

Note. Source: Editorial Office of the Journal of Contemporary Administration (RAC), reflecting the position of editorial management as of March 11, 2021. The last column displays the percentage variation between the first and last periods.

\section{FUTURE CHALLENGES FOR THE RAC}

Considering indications that the shortest stay of an editor in charge of a journal results in a better use of the learning acquired by the editor and an improvement in the editorial process of the journal, personally I believe that remaining as editor for more time may end up being negative overall. This may occur because during this time one may: not take advantage of the energy that new (not necessarily younger) editors may provide, miss taking advantage of new ideas and concepts that are latent in the community, induce complacency in the editor and Editorial Office's rhythm of work, and prevent the editor from reflecting on his or her experience in other spheres of the community, which may offer synergy with the experience acquired in the editorial management process.

For this reason, it is undeniable that even if the journal has advanced in several areas, it is inevitable that the development process will be permanent, and there will always be much to do, especially when resources are scarce. Therefore, challenges are part of the work of an editor. With the intention of making a small contribution to the future work agenda, here are a few aspects that I believe deserve special attention based on the $R A C$ s mission with the community's patrimony, which have been constructed based on the collaboration between editors and authors (I would like to register here my recognition of the work developed by my predecessors: Clóvis Machado-da-Silva - 1997-2001, César Gonçalves Neto - 2001-2002, Tomás de Aquino Guimarães - 2002-2005, Rogério Hermida Quintella 2006-2012, and Herbert Kimura - 2012-2018, who have run the $R A C$ since its founding).

- Developing the quality and velocity of the received reports. Anonymous evaluators constitute an essential part of the editorial process and should receive special attention. The $R A C$ counts on hundreds of people who donate their time to this role, but we do need to diversify, expand, train, and recognize the work of these people who are becoming rarer and rarer.

Consolidating the open science policy. The initiative of promoting transparency, which was introduced in the middle of 2018, constitutes a key to growth and consolidation of the $R A C$ s reputation, so that the journal will be in line with the modern editorial practices that have been adopted around the world.

Exploring the potential of expanding the journal (in a professional and structured manner) via social media. In order to affect society, the convenience of strategies and professional practices (which are not random or on a case-by-case basis) provided by social 
media is undeniable, and this implies the allocation of resources (and not only financial resources).

- By consolidating the journal's reputation as a source of reliable data, we should witness a positive effect of an open science policy that is the accumulation of material shared by our authors. As a result, the journal will become a source of data for conducting research. This may lead to various positive results, e.g.: a reduction in the costs of conducting new studies, the introduction of new researchers who experience difficulties in accessing data, and the attraction of new individuals to $R A C$ s audience (such as the business press).

- Establishing consistent communication channels with society, which together with an open data and material policy, the use of social media, diversification in our corps of evaluators, and the attraction of authors to new contexts, will become viable considering our intention of turning the $R A C$ into an axis between the research community and society.

The attraction of submissions from other countries should naturally receive a boost when the $R A C$ enters the indices of greatest international relevance after our communication efforts with the indices, e.g., its listing in the COPE, our English version of the website, the journal's integral publication in English, and invitations to foreign colleagues to edit special issues, among other initiatives.

The establishment of its editorial identity. It does not appear to be reasonable, at least in the opinion of this editor, to establish the identity of a scientific journal based on the language in which the works are published. Instead, we should seek to emphasize the delineation of the journal's scope and mission. During my tenure, great efforts have been made to adopt a scope that more clearly contributes to the community, even if this means satisfying the demands of international indices and certification bodies with which the $R A C$ has sought to communicate in order to achieve a closer relationship by shining a light on its role.

Investing effort into identifying alternative ways to achieve financial sustainability, bearing in mind the growing financial restrictions that limit the growth and professionalization of this journal. Even though the efforts made to overcome these difficulties are laudable, we need to reflect on how to diversify the risk of financially sustaining the $R A C$, e.g., permitting the perception of donations by individuals and organizations without compromising the smoothness of the editorial process.

- Structure follows strategy. In terms of the challenges facing the $R A C$, I leave the suggestion that not only should the journal's ends be clearly defined, but it should also be structured based on its various kinds of resources.

I hope we will emerge from this pandemic with our health and greater knowledge. I wish to thank the community very much for its trust and for having been given the opportunity to learn. See you soon, and good luck to the new Editor-in-Chief of the RAC.

Table 2. Articles published in the RAC most frequently cited in the Web of Science (as of March 3, 2021).

\begin{tabular}{|c|c|c|c|}
\hline No. & Title & URL for direct access to the article & $\begin{array}{c}\text { \# of } \\
\text { citations }\end{array}$ \\
\hline 1 & Construindo o conceito de competência & https://doi.org/10.1590/S1415-65552001000500010 & 107 \\
\hline 2 & $\begin{array}{l}\text { Content analysis as a qualitative data analysis technique in the field of } \\
\text { administration: potentials and challenges }\end{array}$ & https://doi.org/10.1590/S1415-65552011000400010 & 69 \\
\hline 3 & Research process and bibliometric analysis: bank service quality assessment & https://doi.org/10.1590/S1415-65552013000300005 & 39 \\
\hline 4 & $\begin{array}{l}\text { Produção cientifica em administração de empresas: provocaçôes, insinuaçōes e } \\
\text { contribuiçôes para um debate local }\end{array}$ & https://doi.org/10.1590/S1415-65551999000100009 & 34 \\
\hline 5 & What is a theoretical essay? & https://doi.org/10.1590/S1415-65552011000200010 & 33 \\
\hline 6 & $\begin{array}{l}\text { Patterns of productivity of Brazilian authors in accounting magazines and } \\
\text { congress: a study bibliometric }\end{array}$ & https://doi.org/10.1590/S1415-65552008000200011 & 25 \\
\hline 7 & The field of studies of inter-organizational cooperation networks in Brazil & https://doi.org/10.1590/S1415-65552010000300005 & 22 \\
\hline 8 & A tradição anglo-saxônica nos estudos organizacionais brasileiros & https://doi.org/10.1590/S1415-65552001000500005 & 21 \\
\hline 9 & $\begin{array}{l}\text { A bibliometric approach to Brazilian scientific production on corporate social } \\
\text { responsibility - CSR }\end{array}$ & https://doi.org/10.1590/S1415-65552009000500006 & 20 \\
\hline 10 & A proposição de uma taxonomia para análise da gestão ambiental no Brasil & https://doi.org/10.1590/S1415-65552004000400005 & 20 \\
\hline 11 & Um modelo para o compartilhamento de conhecimento no trabalho & https://doi.org/10.1590/S1415-65552006000200005 & 19 \\
\hline
\end{tabular}


Table 2. (Continued)

\begin{tabular}{|c|c|}
\hline No. & Title \\
\hline 12 & $\begin{array}{l}\text { Corporate Governance and determinants of capital structure: empirical } \\
\text { evidence from Brazilian markets }\end{array}$ \\
\hline 13 & $\begin{array}{l}\text { Scientific cooperation among graduate programs in the field of business in } \\
\text { Brazil: structural evidence in four thematic areas }\end{array}$ \\
\hline 14 & $\begin{array}{l}\text { Environmental sustainability: a meta-analysis of production in brazilian } \\
\text { management journals }\end{array}$ \\
\hline 15 & Competitiveness models for tourist destinations into the sustainability context \\
\hline 16 & Happiness at work: relations with organizational support and social support \\
\hline 17 & Entrepreneurial profile and organizational performance \\
\hline 18 & $\begin{array}{l}\text { Perfil das pesquisas em contabilidade de custos apresentadas no EnANPAD no } \\
\text { periodo de } 1998 \text { a } 2002\end{array}$ \\
\hline 19 & Avaliação e seleção de fundos de investimentos: um enfoque sobre múltiplos atributos \\
\hline 20 & $\begin{array}{l}\text { O processo de internacionalização na ótica da escola nórdica: evidências empiricas } \\
\text { em empresas brasileiras }\end{array}$ \\
\hline
\end{tabular}

21 Aplicação dos princípios da governança corporativa ao sector público

22 Dynamic Capabilities: What Are They and How to Identify Them?

23 Indicadores de desempenho como direcionadores de valor

URL for direct access to the article

https://doi.org/10.1590/S1415-65552008000300009

https://doi.org/10.1590/S1415-65552010000700005

https://doi.org/10.1590/S1415-65552007000300009

https://doi.org/10.1590/S1415-65552001000300002

https://doi.org/10.1590/S1415-65552003000100006

https://doi.org/10.1590/S1415-65552007000200002

Pesquisa de satisfação de clientes: o estado-da-arte e proposição de um método

25 Ativos intangiveis, ciclo de vida e criação de valor

https://doi.org/10.1590/S1415-65552003000100003

https://doi.org/10.1590/S1415-65551998000100007 15

Consumidores satisfeitos, e então? Analisando a satisfação como antecedente da
lealdade

https://doi.org/10.1590/S1415-65552006000300005

https://doi.org/10.1590/S1415-65552004000200004 14

27 Fatores determinantes da estrutura de capital para empresas latino-americanas

https://doi.org/10.1590/S1415-65552003000100002

8 Tecnologias de informação móveis, sem fio e ubiquas: definições, estado-da-arte e oportunidades de pesquisa

29 Pesquisa científica da área de marketing: uma revisão histórica

30 The crossroads of organizational learning: a multiparadigmatic view

https://doi.org/10.1590/S1415-65552007000400009

https://doi.org/10.1590/S1415-65552006000200010 14

https://doi.org/10.1590/S1415-65552010000200008 13

$O$ discurso e a prática: o que nos dizem os especialistas e o que nos mostram as práticas das empresas sobre os modelos de gestão de recursos humanos

https://doi.org/10.1590/S1415-65552

2 The strategic dimension of the horizontal networks of SMOs: theorizations and evidences

33 Entrepreneurship and economic growth: some empirical evidence

https://doi.org/10.1590/S1415-65552004000500011

https://doi.org/10.1590/S1415-65552008000400005

4 Confiança, valor percebido e lealdade em trocas relacionais de serviço: um estudo com usuários de Internet Banking no Brasil

https://doi.org/10.1590/S1415-65552005000200008

Interorganizational relationships and results: a study in a network of horizontal cooperation of the central region of Paraná

https://doi.org/10.1590/S1415-65552011000100003

Gestão de pessoas por competências: o caso de uma empresa do setor de telecomunicaçóes

37 A identidade e o contexto organizacional: perspectivas de análise

https://doi.org/10.1590/S1415-65552000000100009 12

https://doi.org/10.1590/S1415-65552003000500004 12

Estratégia, fatores de competitividade e contexto de referência das organizaçōes: uma análise arquetípica

39 A prática social de gerentes universitários em uma instituição pública

https://doi.org/10.1590/S1415-65552002000300002 12

https://doi.org/10.1590/S1415-65552005000300002 12

Social networks in the scientific production of postgraduate programs of accounting sciences in Brazil

https://doi.org/10.1590/S1415-65552011000100004

Responsabilidade social corporativa: uma investigação sobre a percepção do consumidor 
Table 2. (Continued)

\begin{tabular}{|c|c|c|c|}
\hline No. & Title & URL for direct access to the article & $\begin{array}{l}\text { \# of } \\
\text { citations }\end{array}$ \\
\hline 43 & $\begin{array}{l}\text { Tangibility and intangibility in determining the persistent performance of } \\
\text { Brazilian firms }\end{array}$ & https://doi.org/10.1590/S1415-65552010000500007 & 11 \\
\hline 44 & $\begin{array}{l}\text { Factors that influence the university-industry technology transfer process: the } \\
\text { case of PUCRS }\end{array}$ & https://doi.org/10.1590/S1415-65552012000100005 & 11 \\
\hline 45 & $\begin{array}{l}\text { Proposta para avaliação da gestão do conhecimento em entidade filantrópica: o caso } \\
\text { de uma organizaçâo hospitalar }\end{array}$ & https://doi.org/10.1590/S1415-65552003000400009 & 11 \\
\hline 46 & $\begin{array}{l}\text { Modelagem de equaçôes estruturais e satisfação do consumidor: uma investigação } \\
\text { teórica e prática }\end{array}$ & https://doi.org/10.1590/S1415-65552000000300007 & 11 \\
\hline 47 & $\begin{array}{l}\text { The effect of the degree of internationalization on the international competences } \\
\text { and financial performance of Brazilian SMEs }\end{array}$ & https://doi.org/10.1590/S1415-65552012000300007 & 11 \\
\hline 48 & $\begin{array}{l}\text { The Brazilian management graduate program network: analysis of academic } \\
\text { relationships and the attributes of programs }\end{array}$ & https://doi.org/10.1590/S1415-65552009000400004 & 11 \\
\hline 49 & Estrutura de controle das companhias brasileiras de capital aberto & https://doi.org/10.1590/S1415-65552002000100002 & 11 \\
\hline 50 & $\begin{array}{l}\text { Avaliação da satisfação do consumidor utilizando o método de equaçôes estruturais: } \\
\text { um modelo aplicado ao setor elétrico brasileiro }\end{array}$ & https://doi.org/10.1590/S1415-65552004000400002 & 11 \\
\hline
\end{tabular}

Note. Source: Prepared by the author based on data kindly collected by Professor Luciano Rossoni on the Web of Science platform on March 3, 2021.

\section{REFERENCES}

Aguinis, H. \& Solarino, A. M. (2019). Transparency and replicability in qualitative research: The case of interviews with elite informants. Strategic Management Journal, 40(8), 12911315. https://doi.org/10.1002/smj.3015

Aguinis, H., \& Vaschetto, S. J. (2011). Editorial responsibility: Managing the publishing process to do good and do well. Management and Organization Review, 7(3), 407-422. https://doi.org/10.1111/j.1740-8784.2011.00223.x

American Chemical Society. (2017, October 17). Introduction to ACS reviewer lab [Video file]. Video posted to https://www.youtube.com/watch?v=6ZlQmBq-ry4

Arruda Filho, E. J. M., Muylder, C. F., Cançado, A. C., Dholakia, R. R., \& Paladino, A. (2019). Technology perspectives and innovative scenarios applied in the Amazon region. Revista de Administração Contemporânea, 23(5), 607-618. https://doi.org/10.1590/1982-7849rac2019190303

Bandi, F. M., \& Patton, A. J. (2019). Farewell editorial. Journal of Financial Econometrics, 17(3), 339-340. https://doi.org/10.1093/jjfinec/nbz023

Carvalho, J. V. F., Flores, E., \& Valdez, E. A. (2020). Call for papers: Insurance industry. Revista de Administração Contemporânea. Zenodo. http://doi.org/10.5281/zenodo.3900264

Chimenti, P., \& Marques, L. (2020). Teaching Covid-19's Impact on Business. Revista de Administração Contemporânea. Zenodo. http://doi.org/10.5281/zenodo.3744800
Ethiraj, S., Gambardella, A., \& Helfat, C. (2016). Replication in strategic management. Strategic Management Journal, 37(11), 2191-2192. https://doi.org/10.1002/smj.2581

Kimura, H. (2018). Editorial: O aprendizado em editoração científica. Revista de Administração Contemporânea, 22(3), 1-3. https://doi.org/10.1590/1982-7849rac2018180104

Kumar, P., \& Zattoni, A. (2019). Farewell editorial: Exiting editors' perspective on current and future challenges in corporate governance research. Corporate Governance an International Review, 27(1), 2-11. https://doi.org/10.1111/corg.12268

Lanka, E., Lanka, S., Rostron, A., \& Singh, P. (2019). Research methods in qualitative management research. Revista de Administração Contemporânea. Zenodo. http://doi.org/10.5281/zenodo.3934265

Leal, C. C., Oliveira, B., Branco-Illodo, I., \& Salvador, M. L. E. (2020). Call for papers: Nudging and choice architecture. Revista de Administração Contemporânea. Zenodo. http://doi.org/10.5281/zenodo.3900050

Lecompte, M., \& Goetz, J. P. (1982). Problems of reliability and validity in ethnographic research. Review of Educational Research, 52(1), 31-60. https://doi.org/10.3102/00346543052001031

Marques, L., Chimenti, P., \& Mendes-da-Silva, W. (2021). Teaching COVID-19's impact on businesses. Revista de Administração Contemporânea, 25(Spe), e210064. https://doi.org/10.1590/1982-7849rac2021210064.en 
Martins, H. (2019). Tutorial articles: Guiding the practice of quantitative research. Revista de Administração Contemporânea. Zenodo. http://doi.org/10.5281/zenodo.3558928

Martins, H. C. (2020). Tutorial-articles: The importance of data and code sharing. Revista de Administração Contemporânea, 25(1), e200212. https://doi.org/10.1590/1982-7849rac2021200212

Martins, H. C., \& Perlin, M. S. (2020). Call for papers: Data reuse: What new information can we learn from used data? Revista de Administração Contemporânea. Zenodo. https://doi.org/10.5281/zenodo.3858031

Mendes-da-Silva, W. (2018b). Chamada especial governança corporativa de empresas familiares-RAC. Zenodo. https://doi.org/10.5281/zenodo.2247752

Mendes-Da-Silva, W. (2018a). The promotion of transparency and the impact of research on business. Revista de Administraçâo Contemporânea, 22(4), 639-649. https://doi.org/10.1590/1982-7849rac2018180210

Mendes-da-Silva, W. (2018c). Reconhecimento da contribuição do avaliador anônimo. Revista de Administração Contemporânea, 22(5), 1-13. https://doi.org/10.1590/1982-7849rac2018180281

Mendes-da-Silva, W. (2019a). Convergência, comunicação, e impacto da pesquisa em negócios. Revista de Administração Contemporânea, 23(1). https://doi.org/10.1590/1982-7849rac2019180346

Mendes-da-Silva, W. (2019b). Have we been transparent enough? Challenges in replicability and credibility in business research. Revista de Administração Contemporânea, 23(5). https://doi.org/10.1590/1982-7849rac2019190306

Mendes-Da-Silva, W. (2019c). Relatório de gestão da Revista de Administração Contemporânea 2018-2019. Revista de Administração Contemporânea, 23(6), 1-10. https://doi.org/10.1590/1982-7849rac2019190356
Mendes-Da-Silva, W., \& Leal, C. C. (2021). Salami science na era do open data: Déjà lu e accountability na pesquisa em gestão e negócios. Revista de Administração Contemporânea, 25(1), e200194. https://doi.org/10.1590/1982-7849rac2021200194

Mendes-da-Silva, W., Onusic, L. M., \& Giglio, E. M. (2013). Rede de pesquisadores de finanças no Brasil: Um mundo pequeno feito por poucos. Revista de Administração Contemporânea, 17(6), 739-763. https://doi.org/10.1590/S1415-65552013000600007

Moravcsik, A. (2014). Transparency: The revolution in qualitative research. PS: Political Science \& Politics, 47(1), 48-53. https://doi.org/10.1017/S1049096513001789

Oftedal, E., Bertella, G., Grzegorczyk, M., Hill, P. M., \& Lanka, S. (2020). Call for papers: Business models at the crossroad of responsible innovation, sustainability and resilience. Revista de Administração Contemporânea. Zenodo. http://doi.org/10.5281/zenodo.3754339

Plakoyiannaki, E., Wei, T., \& Prashantham, S. (2019). Rethinking qualitative scholarship in emerging markets: Researching, theorizing, and reporting. Management and Organization Review, 15(Spe. 2), 217-234. https://doi.org/10.1017/mor.2019.27

Plos Media (2021, March 16). Thank you for practicing Open Science [Video file]. Video posted to https://youtu.be/Igsi8c4BjI8)

Rossoni, L., \& Rosa, R. A. (2020). Genesis, impact, and identity of the Journal of Contemporary Administration. Revista de Administraçâo Contemporânea, 24(5), 448-473. https://doi.org/10.1590/1982-7849rac2020200126

Tsang, E. W., \& Kwan, K.-M. (1999). Replication and theory development in organizational science: A critical realist perspective. Academy of Management Review, 24(4), 759780. https://doi.org/10.2307/259353 


\section{Authorship}

\section{Wesley Mendes-da-Silva*}

Fundação Getulio Vargas, Escola de Administração de Empresas de São Paulo.

Rua Itapeva, 474, $8^{\circ}$ andar, 01332-000, São Paulo, SP, Brazil.

E-mail address: rac.wesley.mendes@gmail.com

(1) https://orcid.org/0000-0002-5500-4872

* Corresponding Author

\section{Conflict of Interest}

The author have stated that there is no conflict of interest.

\section{Copyrights}

RAC owns the copyright to this content.

\section{Plagiarism Check}

The RAC maintains the practice of submitting all documents approved for publication to the plagiarism check, using specific tools, e.g.: iThenticate.

\section{SCIENTIFIC EDITORIAL BOARD AND EDITORIAL TEAM FOR THIS ISSUE:}

\section{Editorial Council}

Anielson Barbosa da Silva (UFPB, Joáo Pessoa, Brazil)

Antonio Carlos Gastaud Maçada (UFRGS, Porto Alegre, Brazil)

Ely Laureano Paiva (FGV, São Paulo, Brazil)

Rogério Hermida Quintella (NPGA/UFBA, Salvador, Brazil)

Valmir Emil Hoffmann (UnB, Brasília, Brazil)

Wesley Mendes-da-Silva (FGV/ EAESP, São Paulo, Brazil)

\section{Editor-in-Chief}

Wesley Mendes-da-Silva (FGV/ EAESP, São Paulo, Brazil)

\section{Associate Editors}

Eduardo da Silva Flores (FEA/USP,, São Paulo, Brazil)

Emílio José M. Arruda Filho (UNAMA, Belém, Brazil)

Fabio Caldieraro (EBAPE/FGV, São Paulo, Brazil)

Gilnei Luiz de Moura (UFSM, Santa Maria, Brazil)

Henrique Castro Martins (IAG PUC-Rio, Rio de Janeiro, Brazil)

Ismael Ali Ali (Kent State University, Ohio, USA)

Marcus Cunha Junior (University of Georgia, USA)
Paula Castro Pires de Souza Chimenti (UFRJ/Coppead, Rio de Janeiro, Brazil)

Paulo César Matui (UniGranRio, Rio de Janeiro, Brazil)

\section{Scientific Editorial Board}

André Luiz Maranhão de Souza-Leão (UFPE, Recife, Brazil)

Aureliano Angel Bressan (CEPEAD/UFMG, Belo Horizonte, Brazil)

Bryan Husted (York University, Canada)

Carlos M. Rodriguez (Delaware State University, USA)

Cristiana Cerqueira Leal (Universidade do Minho, Portugal)

Diógenes de Souza Bido (Mackenzie, São Paulo, Brazil)

Erica Piros Kovacs (Kelley School of Business/Indiana University, USA)

Elin Merethe Oftedal (University of Stavanger, Norway)

Fábio Frezatti (FEA/USP, São Paulo, Brazil)

Felipe Monteiro (INSEAD Business School, USA)

Howard J. Rush (University of Brighton, United Kingdom)

James Robert Moon Junior (Georgia Institute of Technology, USA)

John L. Campbell (University of Georgia, USA)

José Antônio Puppim de Oliveira (United Nations University, Yokohama, Japan)

Julián Cárdenas (Freie Universität, Berlin, Germany)

Lucas A. B. de Campos Barros (FEA/USP, São Paulo, Brazil)

Luciano Rossoni (UniGranRio, Rio de Janeiro, Brazil)

M. Philippe Protin (Université Grenoble Alpes, France)

Paulo Estevão Cruvinel (Embrapa Instrumentaçáo, São Carlos, Brazil)

Rodrigo Bandeira de Mello (Merrimack College, USA)

Rodrigo Verdi (MIT Massachusetts Institute of Technology, Cambridge, USA)

Valter Afonso Vieira, (UEM, Maringá, Brazil)

Wagner Kamakura (Jones Graduate School of Business, Rice University, Houston, USA)

\section{Editing}

Typesetting and normalization to APA standards: Kler Godoy (ANPAD, Maringá, Brazil); Simone L. L. Rafael (ANPAD, Maringá, Brazil).

Frequency: Continuous publication.

Circulation: Free open access to the full text.

\section{Indexing and Directories}

Scielo, Redalyc, DOAJ, Latindex, Cengage/GALE, Econpapers, EBSCO, MIAR, Proquest, SPELL, Cabell's, Ulrichs, CLASE, DIADORIM, ERIHPlus, EZB, EuroPub, OasisBR, WorldWideScience, Google Scholar, Capes/Qualis, Citefactor.org, Index Copernicus International, Sherpa Romeo. 